\title{
THE USE OF ASSISTIVE TECHNOLOGY IN THE DEVELOPMENT OF CHILDREN WITH CEREBRAL PALSY
}

\section{${ }^{1}$ Fabio Bruno Campos, ${ }^{1}$ Alex de Oliveira Santos, ${ }^{1}$ Bruno Pereira Gonçalves, ${ }^{1}$ Ronei Nunes Ribeiro, ${ }^{1}$ Jean Mark Lobo de Oliveira and ${ }^{2, *}$ David Barbosa de Alencar}

${ }^{1}$ Academic department, University Center FAMETRO, Amazon-Brazil 2Institute of Technology and Education Galileo of Amazon (ITEGAM), Brazil

\begin{tabular}{l}
\hline ARTICLE INFO \\
\hline Article History: \\
Received $08^{\text {th }}$ January, 2020 \\
Received in revised form \\
$19^{\text {th }}$ February, 2020 \\
Accepted $20^{\text {th }}$ March, 2020 \\
Published online $30^{\text {th }}$ April, 2020
\end{tabular}

Key Words:

Assistive Technology; Cerebral Palsy;

Application; Mobile Device.

*Corresponding author: David Barbosa de Alencar,

\begin{abstract}
This article makes a comparison between two assistive technology applications developed for mobile devices, with the objective of verifying how the contributions of these assistants and the development of the child with PC. A questionnaire was prepared for the person responsible for a child with $\mathrm{CP}$ to perform a comparison of applications (Livox and Matraquinha) and data sources necessary for transportation. It is possible to check if the App Livox is the best accompaniment for children with PC, as it was developed exclusively for this audience and has more functions, such as games and games, unlike the App matraquinha.
\end{abstract}

Copyright (C) 2020, Fabio Bruno Campos et al. This is an open access article distributed under the Creative Commons Attribution License, which permits unrestricted use, distribution, and reproduction in any medium, provided the original work is properly cited.

Citation: Fabio Bruno Campos, Alex de Oliveira Santos, Bruno Pereira Gonçalves, Ronei Nunes Ribeiro, Jean Mark Lobo de Oliveira and David Barbosa de Alencar. 2020. "The use of assistive technology in the development of children with cerebral palsy", International Journal of Development Research, 10, (04), 35351-35356.

\section{INTRODUCTION}

About $15 \%$ of the world's population or about 1 billion people live with disabilities. Approximately $90 \%$ of people with disabilities live in developing countries. According to the United Nations Children's Fund (UNICEF), there are about 150 million children with disabilities in the world. Blind people cannot read the instructions presented in visual form only; deaf people cannot understand the content presented only aurally and people with mobility and dexterity problems may not be able to use their arms or fingers to interact with the computer using the standard keyboard or mouse (Muhammad, 2015). Cerebral Palsy (CP) can be described as a group of disorders that affect the development of motor movements that generate attributed activity limitations (Zanini, 2017). The symptoms of $\mathrm{CP}$ vary with people. Because patients with severe $\mathrm{CP}$ may need to use special equipment to be able to walk or perform any daily activity, however, in cases of a person with mild CP, they may be able to walk a little, but may not need special help. With the technological changes that have occurred in recent years, professionals and people responsible for children with
$\mathrm{CP}$ have used Assistive Technology (AT) as a resource to increase, maintain or improve the functional resources of individuals with disabilities. TA includes a wide range of equipment, services and strategies with the aim of mitigating the problems faced by people with CP (Ramirez, 2016). Examples of AT include wheelchairs, electronic communication systems, computer adaptations and thousands of other commercially available devices. Over the past two decades, great attention has been paid to the development and evaluation of technological devices to serve people with disabilities. As explained, the objective of the research is to make a comparison between two assistive technology applications developed for mobile devices in order to verify their contributions in helping and in the development of children with PC.

\section{Theoretical Reference}

Cerebral Paralysis (PC): Cerebral palsy (CP) is a neurodevelopmental disorder resulting from an injury to the developing brain.

It is the most common form of child disability, with prevalence rates between 1.5 and 3.8 per 1,000 births reported worldwide 
(Ryan, 2017). Zanini, Cemin and Peralles, (2017) cite the main commitments associated with CP include:

- Delays in reaching motor skill milestones, such as rolling, sitting alone or crawling;

- Variations in muscle tone;

- Delay in speech development and difficulty in speaking;

- Muscle stiffness and exaggerated reflexes;

- ataxia or lack of muscle coordination;

- Involuntary tremors or movement;

- Swallowing problems;

- Difficulty walking.

Favoring one side of the body; and Neurological problems, such as seizures, intellectual disabilities and blindness. In clinical practice, the treatment of people with $\mathrm{CP}$ seeks to promote and develop functional improvement in daily activities and mobility, reducing the lack of interaction with the environment and the need for help from others in daily activities (Silva, 2017)

Technology and its Influence on Humanity: Technologies are close and present, which we don't even realize are natural things. The technologies that result, for example, in cutlery, plates, pans, stoves, ovens, refrigerators, and industrialized foods and many other products, equipment, and processes that were planned and built so that we can carry out the simple and fundamental task that guarantees our survival which is food. However, technology is not restricted to that, there are many equipments and products that we use in our daily lives are not noticed as technology. Some invade our body, such as prosthesis, food and medication. Glasses, dentures, processed foods and drinks, vitamins and other types of medicines are products resulting from sophisticated technology (Kenski, 2003). According to Kennsid, (Kennsid, 2012) clarifies that, in general, all the other activities we carry out, we need products and equipment resulting from study, planning and specific construction, in the search for better ways of living. The set of knowledge and scientific principles that apply to the planning, construction and use of equipment in a given type of activity is called technology.

As we can see, our current way of life would hardly be possible without technologies. They are part of our daily lives and we no longer know how to live without using them, on the other hand, we have become so used to a huge series of technological products and equipment that we find them almost natural. We didn't even think about how much study, creation and construction was needed to get it into our hands (Müller, 2016). However, we can understand that it is not only the present moment that we live can be called "technological age". In fact, since the beginning of civilization, all ages correspond to the predominance of one in their own way. Primitive man also relied on his natural character of social generation to overcome the difficulties and challenges of climate, food and attack by other animals. Over time these groups have evolved socially and perfected their tools and utensils, we can consider that the evolution of man is confused with the technologies developed and used in each era (Ministério da educação, 2011). We are living in a new technological moment, where the media, as communication and information technology, invade people's daily lives and become part of it.

For its frequent users, they are no longer seen as technologies, but as complementary, as a company, as a continuation of their living and educational space. Therefore, the expansion of the possibilities of communication and information, through equipment such as telephone, television and computer, changing the way we live and learn. Through these, people communicate, acquire information, knowledge and transform their behavior (Silva, 2013)

\section{Assistive Technology}

Assistive technology (AT) allows students with disabilities to increase their accessibility, improving the quality of the learning experience. The potential value of AT for improving learning opportunities for students with disabilities is recognized by many countries. According to Garcia and Galvão Filho (Garcia, 2012) assistive technology is any item, piece of equipment, software program or product system that is used to increase, maintain or improve the functional resources of people with disabilities. Assistive technology gives children with disabilities the same opportunities to participate in educational environments, this technology must be aligned with their skills and needs. In addition, these assistive technology devices are available to help teachers improve their students' functional capabilities by increasing student participation in learning opportunities and involvement in activities (Malaquias, 2012). Assistive technology helps people with difficulties to speak, type, write, remember, point, see, hear, learn, walk and many other things. Assistive technology can be of low technology, such as communication panels made of cardboard or felt, or even more complex devices such as electronic devices, wheelchairs, walkers, devices, educational software, electric elevators, pencil holders, locators. eyes and head trackers and more (Dusik, 2013). Zaqueu, (2012) made the classification of AT category was constituted based on the general guidelines of inclusive educational policy, however it is not definitive and may vary according to authors.

- Matters for daily life;

- Augmentative (supplementary) and alternative communication;

- Computer accessibility features;

- Control system;

- Architectural designs for accessibility;

- Postural adequacy;

- Mobility aid; and Assistance for the deaf or hearing impaired; and others.

AT is developed for a range of disabilities including blindness and low vision, deafness and hearing impairment, problems accessing the computer, PC and others (Malaquias, 2012). Therefore, CP disorders, which can be minimized with the use of adequate TA for each person (Dusik, 2013)

Telephone Applications as Assistive Technology: Smart phone apps are capable of turning a high-performance cell phone into a variety of assistive devices that can improve the lives of millions of people with and without disabilities (Doughty, 2011). Cell phones are an excellent example of an everyday technology that can be reused to be an assistive technology for an individual with a disability. By themselves and through their capabilities to host applications, cell phones increase the independence of individuals with disabilities in a variety of functional areas, including but not limited to - daily life skills, communication, learning and skill development and within others (Sabiá, 2015).While smart phone apps are an 
important source of improvement for people with disabilities in general, groups such as people with learning disabilities should be the focus of future service developments, and new service models need to reflect the diminishing importance of issues such as installation, maintenance and replacement (Doughty, 2011).

\section{MATERIALS AND METHODS}

For the development of this research, the materials used were of documental and bibliographic background, in which two applications were analyzed, Livox and Matraquinha, and are described in more depth about their applications, result and discussion of this research. Descriptive research was adopted to build knowledge and to develop research that will address: assistive technology, cerebral palsy and telephone applications In addition, a quantitative survey was conducted through a questionnaire containing 10 closed objective questions directed to the guardians of children with CP to perform the comparison of the applications, Livox and Matraquinha, in order to verify which of the two helped in the development and the aid of children diagnosed with $\mathrm{CP}$.

\section{RESULT AND DISCUSSION}

\section{Applications to Help Children with Cerebral Palsy}

As seen throughout the work, TA is any item, equipment or product system, commercially purchased, modified or customized, used to increase, maintain or improve the functional capabilities of people with disabilities (Muhammad, 2015). There is a lack of studies that have specifically investigated the prevalence and incidence of CP in Brazil, however data from the Ministry of Health (MS) in 2014, it is estimated that in countries considered developed, children with CP can vary from 1.5 to 5,9 / 1,000 Live Births (NV), while in the country considered 7 per 1,000 live births (Brasil, 2015). Based on this, an Application (App) was created capable of helping people with PC to facilitate communication and help children, families and caregivers. Both focus apps are available free of charge for phones with Android (Play Stores) and iOS (APP Store) systems. The first is "Livox" (see figures 1 and 2) uses the Android system, this application was developed by Carlos Pereira, with the objective of helping children with PC or other types of disabilities that compromise speech. The App is classified as an AT that helps in the communication of individuals with $\mathrm{CP}$, this tool adjusts to varying degrees of motor, visual and cognitive difficulties, correcting even the inaccurate touches of people with disabilities. In addition, it is considered an auxiliary resource for literacy and the study of concepts of disciplines, and it also helps individuals to transmit emotions. In figure 1, the "Livox" App open screen (1/A) is shown. In order to use the application, it is necessary to register with basic data such as e-mail and password (1 / B), which can be performed by the person responsible for children with $\mathrm{CP}$. Figure 2 shows the screen some functionalities available in the App "Livox" in which the first 4 quadrants, in image 2 / A, are the feelings that children want to express as: bored, hungry, pain and sad. In the second 4 quadrants, in image 2 / B, are the needs that children want to express as: I want to take the book, I am thinking, I want personal care like bathing or hygiene, I am with loved ones.

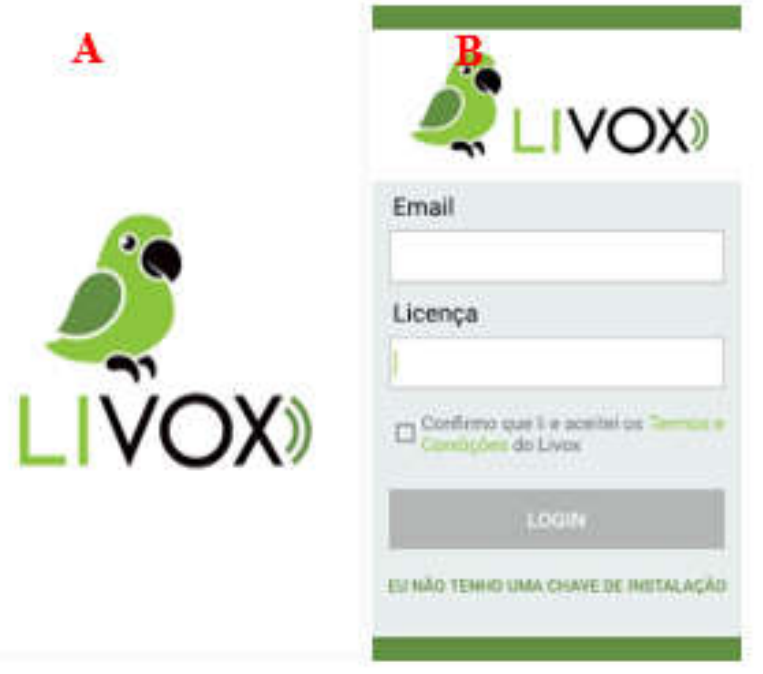

Figure 1 - Opening screen (A) / Registration (B) Source: Play Stores [APP, 2020]

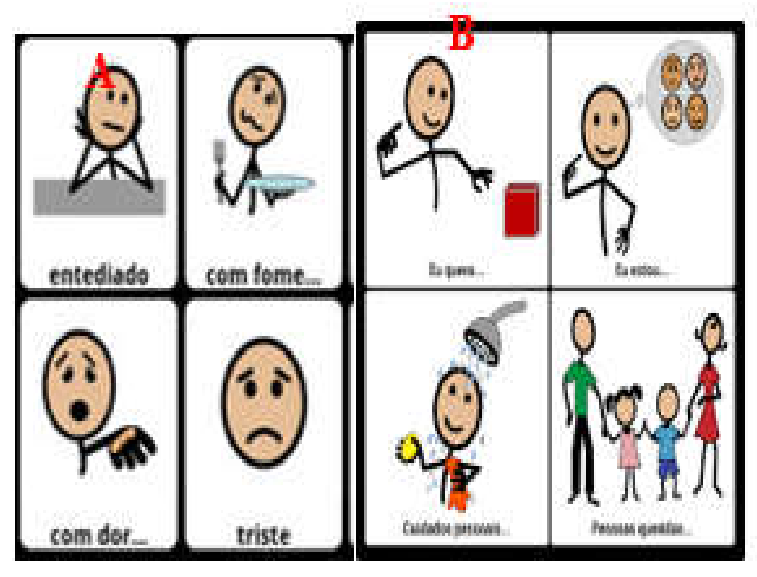

Source: Play Stores [18]

Figure 2. Application features Feelings (A) / Needs (B)

It is worth remembering that in addition to these timeconsuming needs, the app offers other features such as: learning, that children can learn simple knowledge such as: names of animals and good manners. The second application is the "Matraquinha" that uses the Android and iOS system, this application was developed by Wagner Yamuto a programming student to help the child diagnosed with Autistic Spectrum Disorder (ASD).

This App is aimed at the PC user who can express to their caregivers and guardians the activity they want to perform, such as: showering; go to the bathroom; to sleep; drink water; read; play; eat; watching TV and others. Figure 3 shows the initial screen of the App Matraquinha (3 / A) and the home screen (3 / B) in which the child or guardian can select the need to be used at the moment, such as: emotion, need, food, fun, clothes and others. It appears that in this application it is not necessary to register to enjoy the App. Figure 4 shows some features available in the App Matraquinha. In illustration 4 / A the food needs that children with $\mathrm{CP}$ can ask their parents are: water, juice, milk, eating meat, chicken, sausage, pineapple and others. In illustration 4 / B it is pointed out the needs of fun that children with CP can ask the responsible person who are: play, cart, ball, doll, dinosaur, puzzle, coloring, drawing and others. 


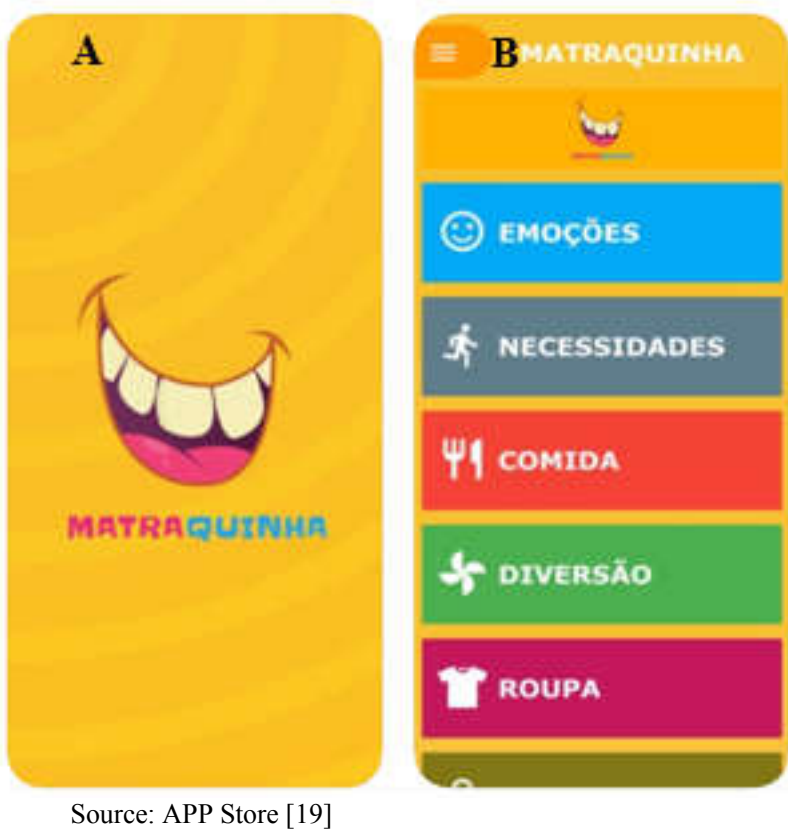

Figure 3 - Home page Opening screen (A) / Home B)

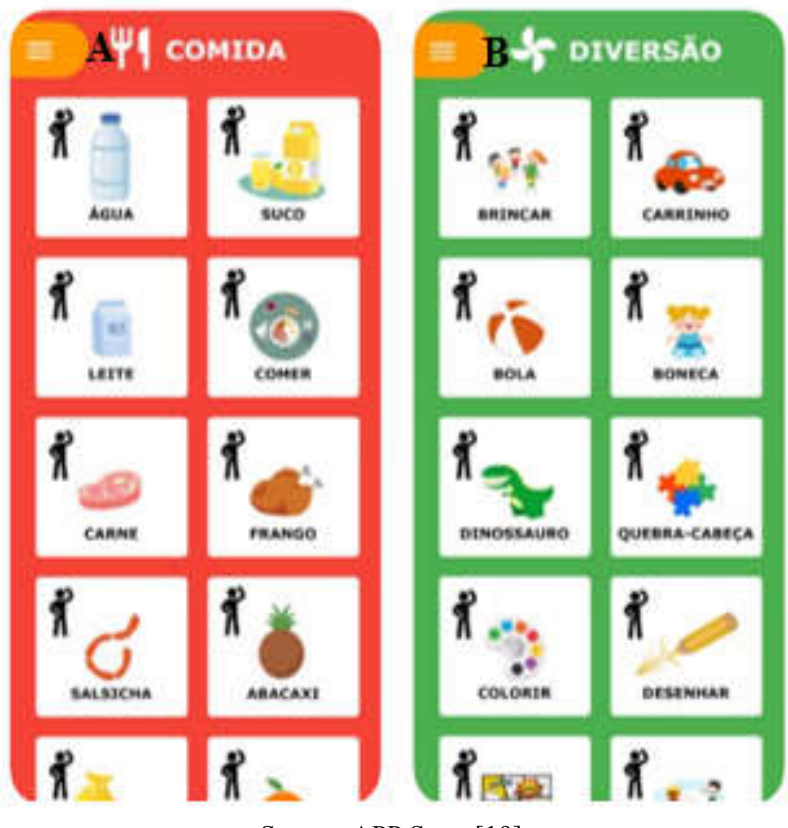

Source: APP Store [19]

Figure 4 - Application features Food Needs (A) / Fun Needs (B)

Description of Children Interviewed With Pc: To achieve the purpose of the research, a questionnaire was applied to the guardians of children with $\mathrm{CP}$, however, it verifies the need to understand the reality and needs of these patients. In order to preserve the identity of these minors, it is decided to use fictitious names, in which the first was named David and the second Gabriel, both diagnosed with CP and 10 years old. Davi has difficulties in performing basic activities, needing help to eat and bathe. He presents difficulties in socializing, preferring to perform some activities alone, as well as sometimes presenting a picture of crying. the child has constant monitoring with other professionals who can help in this teaching-learning process. Gabriel has a calm demeanor but gets irritated easily when he is not understood, has difficulties in socializing with some people, in the cognitive aspect understands and responds to some stimuli. The child has autonomy in some everyday situations such as eating, however, he needs help with others to walk because he walks with ambulation.

\section{QUESTIONNAIRE RESULTS}

The objective of the research was to make a comparison between two applications (Livox and Matraquinha) of AT developed for mobile device in order to verify the contributions of these App in the aid and development of the child with PC. To achieve this intuition, 10 questions were developed and applied, which were answered by those responsible for children diagnosed with $\mathrm{CP}$, and the results are presented in the table below with individual responses from each subject. According to the responses obtained by the responsible person through the questionnaire and the result in Graph 1, it can be pointed out that David used the App Livox and Gabriel used App Matraquinha.

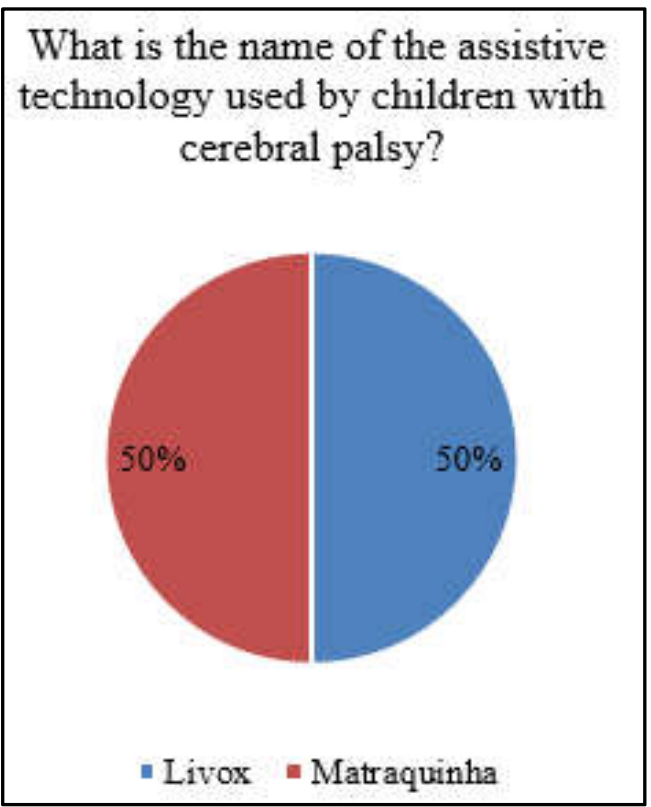

Graph 1. Result of the Inquiry Source: Author, (2020)

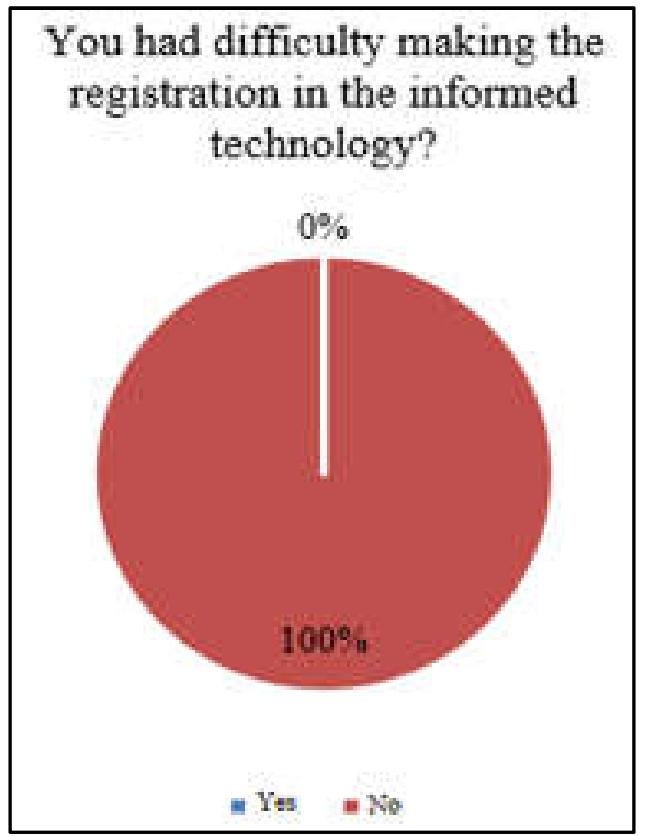

Graph 2. Result of the Inquiry Source: Author, (2020). 


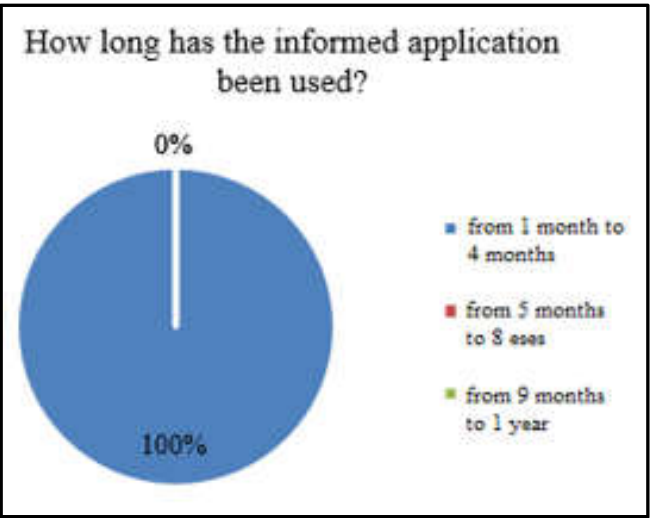

Graph 3. Result of Inquiry Source: Author, (2020)

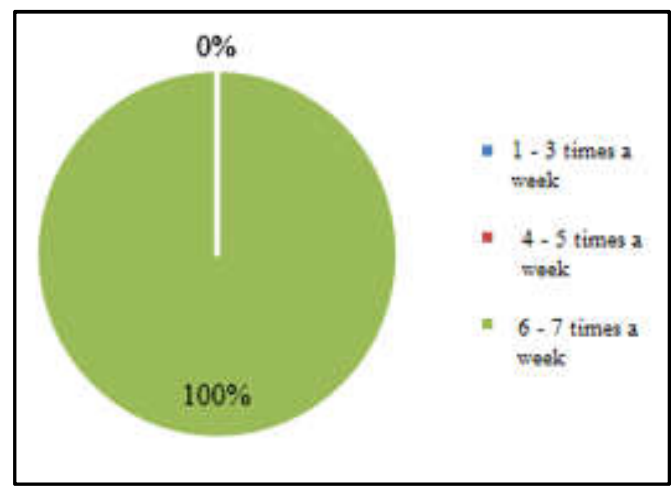

Graph 4. Result of the Inquiry Source: author (2020)

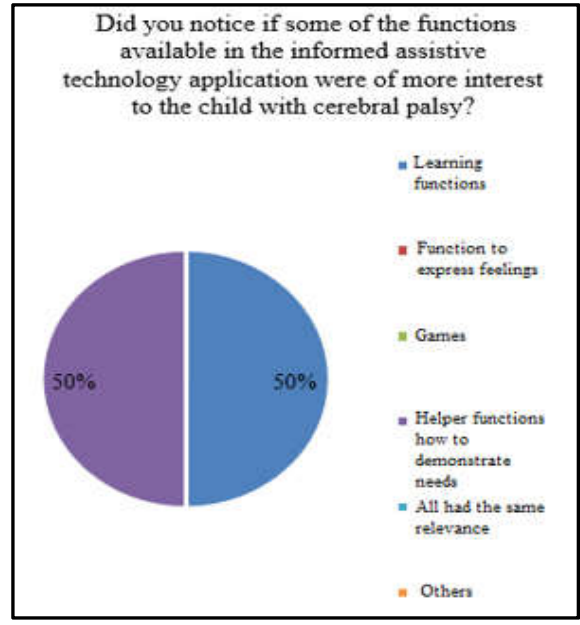

Graph 5. Result of Inquiry Source: Author, (2020)

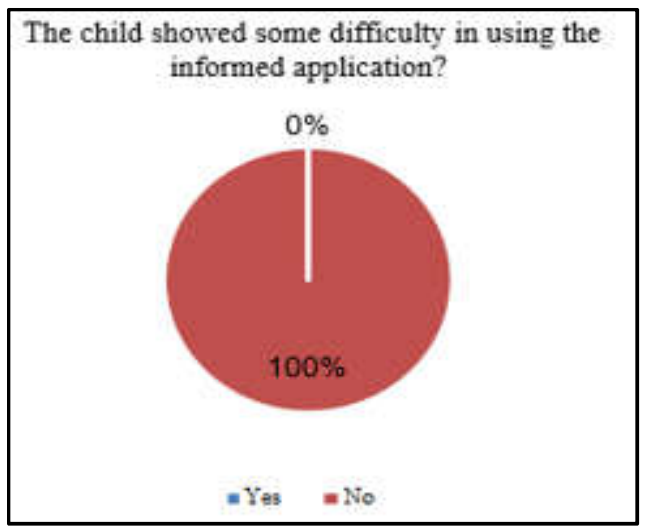

Graph 6 - Result of Inquiry Source: Author, (2020)

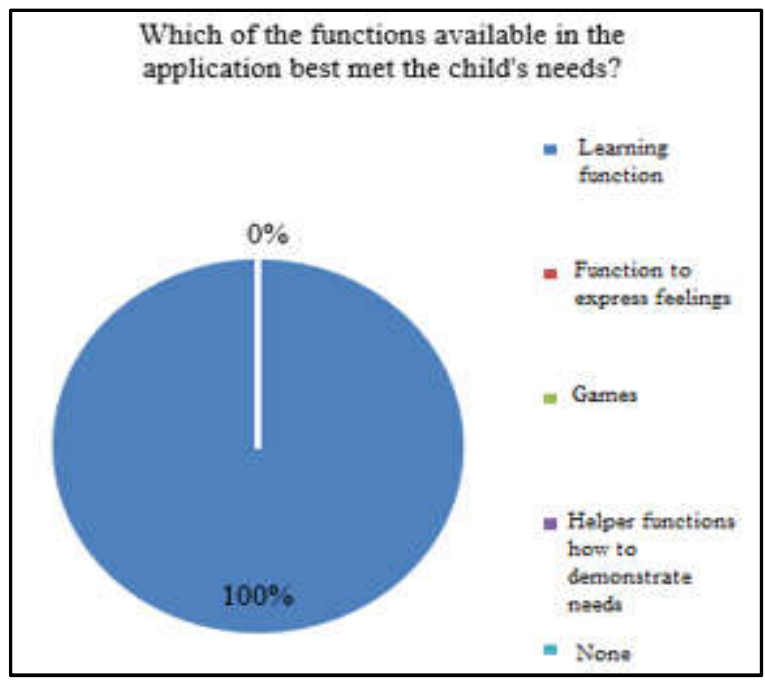

Graph 7. Result of Inquiry Source: Author, (2020)

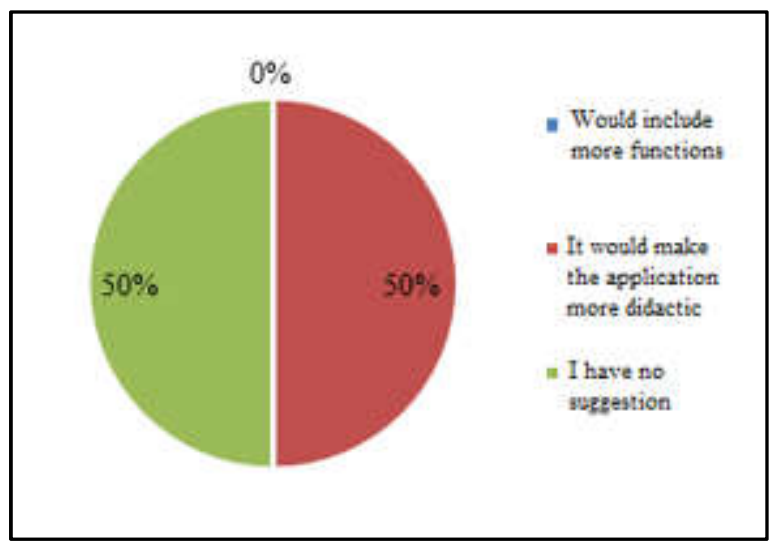

Graph 8. Result of Inquiry Source: Author, (2020)

According to responses obtained by those responsible through the questionnaire and the result in Graph 2, both cases had no difficulty in registering with the informed technology. So question number 3 (If question 2 is yes. What was the difficulty?) Does not apply because the answer to question 2 was negative. According to responses obtained by the guardians through the questionnaire and the results of graphs 3 and 4, both children with CP used their respective App between 1 month to 4 months on 7 days a week. Therefore, it is understood that the two App have been usability by both children. According to the responses obtained by those responsible through the questionnaire and the result in Graph 5, David's parents informed that they were the learning functions because they instigated the child through the didactic way. Gabriel's parents informed that it was the help functions such as demonstrating needs because the child is often unable to express himself, which makes care difficult. It appears that there is a distinction in the answers given which can be motivated by the individual differences of the App, because the matriquinha does not have available in its educational or games and games functions, assisting only in alternative communication to help children and adolescents transmit their desires, feelings and needs. According to responses obtained by those responsible through the questionnaire and the result in Graph 6, in both cases the responses were negative. Therefore, both App are able to meet the usability needs of children with PC. So question number 3 (If question seven is yes. What was the difficulty?) Does not apply because the answer to question 7 was negative. 
According to the responses obtained by those responsible through the questionnaire and the result in Graph 7, the response of the person in charge of Davi and Gabriel were the help functions such as demonstrating needs, similar results were motivated by the basic need of patients with $\mathrm{CP}$ who, in most cases, did not they can ask for help in some everyday situations like eating. According to the responses obtained by the guardians through the questionnaire and the result in Graph 8 , the response of the guardian of Davi was none, and the response of the guardian of Gabriel was the need for the App to be more didactic, making new functions to arouse the child's interest. It is also worth remembering that the difference in the answers that can be motivating for the needs of the different children of each child, because as it seems, Davi has difficulties in carrying out basic activities, that is, children need more the help functions such as demonstrating needs, while Gabriel has autonomy in some everyday situations, that is, he needs assistance in the development of skills and / or knowledge.

\section{Conclusion}

With the information presented throughout the study, it is highlighted that the execution and realization of this study are feasible, because all the objectives proposed to the beginning of the work were successfully achieved. It is worth mentioning that all the information and data cited in this research are real, reliable and valuable information; tools that will contribute as an instrument of interest for further study on the topic. The research revealed that the use of AT are strong components in the development process of children with some type of disability, that is, for children with $\mathrm{CP}$, the use of activities present in these technological environments serves to assist and motivate children, in addition to help in the expression of feelings and needs, so the technology is expanded to real contact with other people, creating from there affective bonds and social interaction with the environment in which it is inserted. Regarding analysis with the questionnaire, it was found that the results were not $100 \%$ conclusive due to the limitations of the study, such as having only two research subjects and not being able to carry out a follow-up for a longer period, as the study took place for only one month. However, it can be seen that the App Livox is the one that best meets the needs of children with PC because it is developed exclusively for this audience and because it has more functions such as games and play, which is not the case with the App. For future studies, we suggest the development of other applications that reach the same audience because most of the available platforms are for children with autism, which does not meet the needs of these people with PC since it does not have only a deficit in communicating, but it also has learning difficulties. In other words, it is necessary to develop an App that supports speech expression, learning and development.

\section{Acknowledgment}

First of all, we would like to thank God. We also thank our advisor Bruno Pereira Gonçalves for agreeing to conduct our research work. To all our teachers in the Information System Course at Centro Universitário Fametro for the excellence of the technical quality of each one. To our parents who have always been by our side supporting us throughout our trajectory and to everyone who participated directly or indirectly in our trajectory throughout our training. Our sincere thanks!

\section{REFERENCES}

APP Store 2020. Matraquinha. Disponível em: https://apps.apple.com/br/app/matraquinha/id1423586611. Acesso em: 28 de mar de 2020

Brasil. Ministério da Saúde. Secretaria de Atenção à Saúde. Departamento de Ações Programáticas Estratégicas. Diretrizes de atenção à pessoa com paralisia cerebral / Ministério da Saúde, Secretaria de Atenção à Saúde, Departamento de Ações Programáticas Estratégicas. Brasília : Ministério da Saúde, 2014.

Doughty, Kevin. SPAs (smart phone applications)-a new form of assistive technology. Journal of assistive technologies, 2011.

Dusik, 2013. Cláudio Luciano. Teclado virtual silábico-alfabético: tecnologia assistiva para pessoas com deficiência física.

Garcia, Jesus Carlos Delgado; GALVÃO FILHO, 2012. Teófilo Alves. Pesquisa nacional de tecnologia assistiva. São Paulo: ITS Brasil/MCTI-Secis.

Kennsid, Vani Moreira. 2012. Tecnologia e ensino presencial e a distância $-9^{a}$ ed. Campinas, SP: Papirus.

KENSKI, Vani Moreira. 2003. O que são tecnologias? Como convivemos com as tecnologias. KENSKI, Vani Moreira. Tecnologias e ensino presencial e a distância. Campinas: Papirus.

Malaquias, 2012. Fernanda Francielle de Oliveira et al. Realidade virtual como tecnologia assistiva para alunos com deficiência intelectual.

MEC, Ministério da educação. 2011. TV na escola e os desafios de hoje: Curso de Extensão para Professores do Ensino Fundamental e Médio da Rede Pública. UniRede e Seed/MEC/Coordenação de Leda Maria Rangearo Fiorentini e Vânia Lúcia Quintão Carneiro. - Brasília : Editora Universidade de Brasília, 2a. ed.

Muhammad, Aslam et al., 2015. Assistive technology for disabled persons. In: International Conference on Recent Advances in Computer Systems. Atlantis Press.

MÜLLER, Jaqueline et al. 2016. A Utilização Dos Recursos Tecnológicos No Processo Pedagógico De Crianças E Adolescentes Hospitalizados.

Play Stores. Livox 2020. Disponível em: https://play.google.com/store/apps/details?id=br.com.livox\&h l=pt_BR. Acesso em: 28 de mar de 2020.

RAMIREZ, Alejandro Rafael Garcia et al., 2016. Assistive and Adaptive Technology in Cerebral Palsy. Cerebral Palsy: Current Steps, p. 173.

RYAN, Jennifer M. et al., 2017. Exercise interventions for cerebral palsy. Cochrane Database of Systematic Reviews, $n$. 6.

SABIÁ, Juliana Braga; SILVA, Márcia Cristina De Araújo. O uso de dispositivos de tecnologia assistiva utilizados por terapeuta ocupacional no contexto escolar: uma revisão de literatura. Saúde. Com-Ciência ISSN: 2594-5890, n. 1, 2015.

SILVA, 2013. Sabrine Denardi de Menezes da. Mídia e educação: O uso das novas tecnologias em sala de aula.

SILVA, Michely Salvador; DALTRÁRIO, Sandra Mara Beltrami. 2017. Paralisia cerebral: desempenho funcional após treinamento da marcha em esteira. Fisioterapia em Movimento, v. 21, n. 3.

ZANINI, Graziela; CEMIN, Natália Fernanda; PERALLES, Simone Nique. 2017. Paralisia cerebral: causas e prevalências. Fisioterapia em Movimento, v. 22, n. 3.

Zaqueu, Livia da Conceição Costa. Política Educacional Inclusiva I. Universidade Federal do Maranhão, 2012. 